\title{
Befogging reason, undermining will: Understanding sleep deprivation as torture and other ill-treatment in international law
}

\author{
Ergün Cakal, LLM*
}

Sleeplessness befogs the reason, undermines the will, and the human being ceases to be himself, to be his own 'I'.

- Solzhenitsyn in The Gulag Archipelago

\section{Key points of interest}

- Sleep deprivation is prohibited by international law but there is a dearth of informed analysis regarding its individual (subjective) and contextual (environmental) complexities.

- There is a considerable body of medical knowledge to be extrapolated in order to formulate workable definitions and limitations.

\section{Abstract \\ Background: Sleep deprivation is a prevalent method of psychological torture. However, difficulties in documentation have meant that it is not adequately appreciated by courts and other quasi- judicial institutions such as UN treaty bodies. Method: This paper aims to review}

^) Legal Advisor, DIGNITY - Danish Institute Against Torture, Copenhagen

Correspondence to: erca@dignity.dk the legal literature on deprivation of sleep, the definition, and prohibition of torture and ill-treatment, and its health impacts. A number of texts were identified and analyzed based on contextual relevance: criminal justice processes as well as medical literature on health impacts. The texts were identified via a search of key legal and health databases using the search terms "sleep deprivation," "sleep adjustment," and "sleep regulation." These texts were limited to English-language journal articles, NGO reports, court-cases and UN documents since 1950. They were then analyzed for their approaches to conceptualizing sleep deprivation from the perspective of assessing "severe pain and suffering" and the "diminishment of mental capacity." Results/Discussion: Sleep deprivation is an ill-defined and, in turn, poorly documented method of torture, particularly when prolonged or inflicted in combination with other methods (e.g., threats) and conditions (e.g., disruptive environment or time of day). More nuanced legal principles, informed by medical evidence, are lacking. Applying these principles would sharpen its conceptualization.

Keywords: Sleep deprivation, sleep disruption, adequate rest, psychological torture, interrogation 


\section{Introduction}

\section{Objective and Method}

The use of sleep deprivation has been recognized by the international human rights framework as a method of torture or cruel, inhuman and degrading treatment or punishment (hereafter "other ill-treatment"). However, its temporal and contextual dimensions require a clearer definition. The related concept of "adequate sleep" - as a safeguard (or, more broadly, rest) for those under interrogation, arrest or detentionis also ill-defined and lacks clarity. This paper aims to review the legal literature on deprivation of sleep, the definition, and prohibition of torture and ill-treatment, and its health impacts.

A desk review was undertaken based on primary (i.e., case-law and institutional reports) and secondary literature (i.e., expert reports, commentaries, and metastudies) pertaining to the deprivation of sleep, whether intentional or consequential. Particular attention was given to criminal justice contexts as well as medical literature on health impacts. The texts were identified via key legal and health databases (i.e., HeinOnline, HUDOC, UNODS and DIGNITY's Documentation Centre) using the search terms "sleep deprivation," "sleep adjustment," and "sleep regulation." The review encompasses legal and, to a lesser extent, medical literature.

These texts were analyzed for their respective approaches to conceptualizing sleep deprivation from both legal and medical perspectives, particularly with the objective of assessing "severe pain and suffering" and the "diminishment of mental capacity". Whilst the approach taken is deductive, non-legal considerations not explicitly referenced in the text of court decisions could not be reviewed.
Some categorizations treat sleep deprivation through the broader discussion of sleep disruption, which also includes sleep interruption, adjustment, and manipulation as a consequence of other methods of illtreatment. The discussion here, however, is primarily focused on sleep deprivation.

\section{Definition and Purpose}

There is no universally accepted legal definition of what constitutes sleep deprivation or what is sometimes referred to as "prolonged" sleep deprivation. When the broader discourse on psychological methods of torture is surveyed, the dearth of any workable definitions of methods, with the recent exception of solitary confinement (now defined in the Nelson Mandela Rules), becomes apparent. ${ }^{1}$ In their work on Guantánamo Bay, Physicians for Human Rights (PHR) and Human Rights First (HRF) put forward a definition of sleep deprivation as the deprivation of "normal sleep for extended periods through the use of stress positions, sensory overload, or other techniques of interrupting normal sleep" (PHR \& HRF, 2007, p. 22). However, what is considered "extended periods" or "normal sleep" is not concretely defined. Indeed, perhaps they cannot be defined due to contextual and subjective factors, as later discussed.

Medical literature depicts sleep deprivation with more clarity. The following categorizations are regularly used: "longterm total sleep deprivation $(>45 \mathrm{~h}$ ), shortterm total sleep deprivation $(\leq 45 \mathrm{~h})$ and partial sleep deprivation $(<7 \mathrm{~h}$ in a $24 \mathrm{~h}$ period)" (Leach, 2016, p. 17). Other terms in the literature generally include sleep

See Cakal (2018) for a lengthier discussion on conceptualizing psychological torture. 
restriction, which is comparable with partial sleep deprivation. These are not, however, consistently used across all studies.

Historically, sleep deprivation has been used for a number of different objectives but, primarily, to cause stress and duress for the purpose of coercing information and confessions (see Rejali, 2007, pp. 290292). According to Pérez-Sales (2016), sleep deprivation is one method, among others, to "prolong the shock of capture and prevent the detainee from recovering, regaining control or making decisions ... [and it] increases the perception of pain and it diminishes the capacity to react in complex adverse situations" ( $\mathrm{p}$. 186). It is often applied in interrogation settings. The detention centre with poor conditions is another context in which sleep deprivation, as a consequence of sleep disruption, takes place. This is often due to overcrowding, insufficient or no mattresses, and poor conditions of transportation between the courts and detention facilities. Although case-law on detention conditions will be touched upon, the context of interrogation is the primary focus of the below discussion.

\section{Health Impacts}

While ethical considerations prevent a scientific study from being conducted on detained subjects, controlled medical studies in an experimental setting demonstrate that sleep deprivation can lead to a number of health impacts. Studies, to varying degrees, consistently find an association between sleep deprivation and increased anxiety, higher perception of pain, emotional response, and cognitive functioning (Leach, 2016, p. 7). A multitude of reviews exist in medical literature, which support this analysis (e.g., Beattie et al., 2014; Griffith \& Mahadevan, 2015; Lowe et al., 2017; Pilcher
\& Huffcutt, 1996; Pires et al., 2016; Wickens et al., 2015). Similarly, there is extensive literature anchored in psychology on coercive interrogations, which identify sleep deprivation as a factor that induces false confessions (Davis and Leo, 2012; Kassin et al., 2004).

One review concluded that sleep deprivation may cause "cognitive impairments including deficits in memory, learning, logical reasoning, complex verbal processing, and decision-making" and observed that "sleep restriction of four hours per night for less than a week can result in physical harm, including hypertension, cardiovascular disease, altered glucose tolerance and insulin resistance" (PHR \& HRF, 2007, pp. 22-23). It concluded that the severity of these sequelae can indeed amount to torture or other forms of ill-treatment if used for criminal investigation.

Whether the findings identified in tightly controlled scientific studies are applicable to the real-life situations is debated (see O'Mara 2015 generally). Detention and interrogation conditions are also not simulated as part of these studies. The application of scientific knowledge to an interrogation context, therefore, remains limited.

Drawing the links between what is known and the conditions of detention, Başoğlu speculates that:
"Prolonged exposure to unhygienic or unsanitary conditions, overcrowding, and restriction of movement, together with deprivation of food, water, sleep, and medical care, can pose a serious threat to life, even in the case of a healthy person. Under such conditions, a person would most likely perceive a serious threat to their life. Sleep deprivation is not only a potent stressor in itself but also likely to amplify the impact of other stressors by making effective coping with 
other threatening events difficult. In addition, there is a strong element of humiliation in being exposed to such inhuman conditions." (Basoglu, 2017, p. 27)

However, the established association between sleep deprivation and the outlined health impacts does not necessarily evidence torture.

\section{Sleep deprivation as torture}

International laws pertaining to detention do not explicitly limit interrogation duration, define adequate sleep, nor state when sleep deprivation amounts to torture or other ill-treatment.

The discussion, therefore, needs to be based on authoritative principles under international human rights law, namely Article 1 of the UN Convention Against Torture and Other Cruel, Inhuman or Degrading Treatment or Punishment (UNCAT).

Accepting the premise that sleep deprivation is primarily used for obtaining information or confession, two elements under the definition emerge to be particularly significant: intentionality and severe physical or mental pain or suffering. Notably, Article 3 of the European Convention on Human Rights (ECHR) has also been interpreted to require these two elements. ${ }^{2}$ If these elements cannot be identified, the treatment can still amount to other ill-treatment. This is explored below when reviewing their application to sleep deprivation.

\section{Severity and Duration}

Severe pain or suffering, whether physical or mental, is inflicted by a single method or

2 See ECHR. (1999). Selmouni v. France, 25803/94. \$97; ECHR. (2000). Rehbock v. Slovenia, 29462/95. a combination of methods and can occur on one or on multiple occasions. ${ }^{3}$ It can be either short-lived or prolonged. ${ }^{4}$ However, mental pain alone can constitute torture and need not be coupled with physical pain. Yet, interpreting the term "severe" has proven challenging as it hinges on the level of intensity, which is based on a plethora of factors including duration and a victim's health, age, and sex. Deciphering when sleep deprivation amounts to torture is thus complex and is thus best determined on a case-by-case basis.

The UN Special Rapporteur on Torture and Other Cruel, Inhuman or Degrading Treatment or Punishment (UNSRT) has regularly identified that sleep deprivation is indeed capable of amounting to torture. ${ }^{5}$ During his examination of "enhanced interrogation techniques," as the former UNSRT, Sir Nigel Rodley pointed out that "[e]ach of these measures on its own may not provoke severe pain or suffering" but may do so in combination when "applied on a protracted basis of, say, several hours." ${ }^{\prime}$ Therefore, he considered a certain combination or accumulation of methods and duration as a requirement before the severity threshold becomes particularly relevant. Such declarations have done little to identify a workable definition and to articulate the circumstances under which sleep deprivation amounts to torture.

3 ICTY. (2002). Prosecutor v. Krnojelac. Case No. IT-97-25 (Trial Chamber) 15 March 2002, \$182.

4 CAT. (2006). Conclusions on USA. CAT/C/USA/ CO/2, \$13. ICTY. (2006). Naletilic and Matinovic. Appeal Judgement, 3 May 2006, \$300.

5 UNSRT. (1997). Report. E/CN.4/1997/7, 10 January 1997; UNSRT. (2006). Report. CN.4/2006/6/Add.6; UNSRT. (2010). Report. A/ HRC/13/39/Add.5.

6 UNSRT. (1997). Report. E/CN.4/1997/7, 10 January 1997, \$121. 
Similarly, the UN Committee Against Torture (CAT) has criticized the use of sleep deprivation by a number of states, providing clear indications of outer limits. Most prominently, its observations with respect to the United States focused on the guidelines in the interrogation rulebook in the United States Army Manual: "Use of separation must not preclude the detainee getting four hours of continuous sleep every 24 hours" (US Army, 2006, Appendix M). With the understanding that a detainee could be subjected to this for a renewable period of 30 days, the CAT found that this amounted to "authorizing sleep deprivation - a form of ill-treatment." " Of particular concern was that this rule may be interpreted to allow for 40 continuous hours of interrogation with only four hours of sleep on either side of this protracted period. The United States, when questioned by the CAT, denied that this took place. Similarly, the CAT has also criticized Israel for using sleep deprivation. ${ }^{8}$ Based on the understanding that it is not inherently harmful, CAT did not categorically state that sleep deprivation amounted to torture in all cases, as evidenced by their need to detail the durations concerned.

CAT. (2014). Conclusions on USA. CAT/C/ $\mathrm{USA} / \mathrm{CO} / 3-5, \$ 17$.

8 It found one individual to have been: permitted to sleep for about one hour in 24 over the course of 4 days, which constituted torture from a medical point of view. In another case, brought before the High Court (HCJ 2210/96), the detainee had been kept awake for 39 hours followed by 5 hours' rest, then for 47 hours with 2 hours' rest, and then for 22 hours with 5 hours' rest, 47 hours with 5 hours' rest, 46 hours with 5 hours' rest, and finally 48 hours with 6 hours' rest. The situation had perhaps been urgent, but that unquestionably constituted mental torture. (CAT. (1998). Report. E/CN.4/1998/38, 』24)
Falling Short of Torture: Severity or

Intentionality?

Methods of interrogation that undermine will or capacity have, to date, been accepted as having the capacity to amount to torture and, more often, as other forms of ill-treatment. Principle 6 of the UN Body of Principles for the Protection of All Persons under Any Form of Detention or Imprisonment requires other ill-treatment to be interpreted to include "the holding of a detained or imprisoned person in conditions which deprive him, temporarily or permanently, of the use of any of his natural senses, such as sight or hearing, or of his awareness of place and the passing of time." Drawing on the range of impairments emanating from the medical literature, it is reasonable to interpret this to capture any form of sensory deprivation, blunting of the senses or temporal disorientation, including the use of sleep deprivation.

Conversely, Article 2 of the InterAmerican Convention to Prevent and Punish Torture contemplates diminishment of capacity as torture in the following:

“... any act intentionally performed whereby physical or mental pain or suffering is inflicted on a person for purposes of criminal investigation, as a means of intimidation, as personal punishment, as a preventive measure, as a penalty, or for any other purpose. Torture shall also be understood to be the use of methods upon a person intended to obliterate the personality of the victim or to diminish his physical or mental capacities, even if they do not cause physical pain or mental anguish.”

The link between sleep deprivation and diminishing an individual's personality was further enlightened by the case of Maritza Urrutia v. Guatemala. The Inter-American Commission requested that the Inter- 
American Court find a "violation because of the use of: methods tending to obliterate or diminish her personality, such as sleep deprivation" ( $\$ 78(\mathrm{~b}))$. Without specifically condemning sleep deprivation, the InterAmerican Court in turn ruled that:

“... according to the circumstances of each
particular case, some acts of aggression
inflicted on a person may be classified as
mental torture, particularly acts that have
been prepared and carried out deliberately
against the victim to eliminate his mental
resistance and force him to accuse himself of
or confess to certain criminal conducts, or to
subject him to other punishments, in addition
to the deprivation of freedom itself."

This is also echoed in Principle 1 of the Principles and Best Practices on the Protection of Persons Deprived of Liberty in the Americas, which protects individuals from "forced intervention or coercive treatment, from any method intended to obliterate their personality or to diminish their physical or mental capacities."

To date, the European Court of Human Rights has considered sleep deprivation primarily through Article 3 assessments of detention conditions, predominantly focusing on the conditions that inhibit adequate rest such as transportation, cell overcrowding, lack of comfortable beds, and disruptions caused by the prison environment.

Although removed from the context of interrogation, the discussion of the term "adequate rest" found in this body of jurisprudence is useful. For example, Dougoz v. Greece is an illustrative case

9 Inter-American Commission on Human Rights. (2003). Maritza Urrutia v. Guatemala. 27 November 2003. Series C No. 103, $\$ 93$. where "the serious overcrowding and absence of sleeping facilities, combined with the inordinate length of the period during which he was detained in such conditions, amounted to degrading treatment contrary to Article 3." 10

There has also been a number of Russian cases where transportation conditions - "the frequency and the length of those transfers, of appalling conditions at the prison assembly sections and in the police vans, and about the intensity of the schedule"-has not allowed the applicant to sufficiently sleep and were in violation of Article 3. However, what constituted sufficient sleep was not satisfactorily explained. ${ }^{11}$

Turning to interrogation-oriented uses, Ireland v. the United Kingdom still proves to be an illustrative case. This is perhaps the Court's most (in)famous consideration of sleep deprivation, as part of the "five (torture) techniques." The (now defunct) European Commission of Human Rights, focusing on the combined psychological impacts, found that the five techniques constituted torture on the grounds that intensity directly affects the personality:

$$
\begin{aligned}
& \text { “... the systematic application of the } \\
& \text { techniques for the purpose of inducing a } \\
& \text { person to give information shows a clear } \\
& \text { resemblance to those methods of systematic }
\end{aligned}
$$

10 ECHR. (2001). Dougoz v. Greece, 40907/98. §48; see also ECHR. (2017). Boudraa v. Turkey, $1009 / 16, \$ 36$.

11 See the following cases from the ECHR: Akimenkov v. Russia, 6 February 2018, 2613/13, 50041/14, IS 86-87; Stepan Zimin v. Russia, 30 January 2018, 63686/13, 60894/14, \$\$40-42; Lutskevich v. Russia, 15 May 2018, 6312/13, 60902/14, \$\$61-63; Polikhovich v. Russia, 30 January 2018, 62630/13, 5562/15, \$\$41-43; Kavkazskiy v. Russia, 28 November 2017, 19327/13, \\58-59 
torture which have been known over the ages... a modern system of torture falling into the same category as those systems... applied in previous times as a means of obtaining information and confessions." 12

However, the Court challenged this interpretation and found that the application of the five torture techniques amounted to inhuman and degrading treatment but not torture.

The Court has since considered the use of sleep deprivation in other interrogation contexts. In the Mader v. Croatia case, for example, where the applicant was "deprived of sleep and forced to sit on a chair continuously for two days and nineteen hours" at a police station, the Court found that this alone amounted to inhuman treatment $(\$ 108) .{ }^{13}$ In Bati v. Turkey, where the applicants were subjected to sleep deprivation for several days, as well as physical and verbal assault during interrogation, the Court accepted that this treatment "was liable to harm their mental integrity" ( $(114) .{ }^{14}$

In Bagel v. Russia, the applicant alleged that he had "insufficient time to sleep on the days of transport." Accepting that the applicant was able to sleep at least from $11 \mathrm{pm}$ to $5 \mathrm{am}$ each night, the Court ruled that he was not subjected to any sleep deprivation (\$70). ${ }^{15}$ This precedent was followed more recently in Sadretdinov v. Russia, where the applicant complained of

12 ECommHR (1976). Ireland v. United Kingdom, European Commission of Human Rights, Yearbook of the European Convention on Human Rights, 19, p. 512.

13 ECHR. (2011). Mader v. Croatia, 56185/07.

14 ECHR. (2004). Bati v. Turkey, 33097/96 and $57834 / 00$.

15 ECHR. (2007). Bagel v. Russia, 37810/03. the failure to ensure that he "enjoyed eight hours' sleep on court hearing days" (\$96). The Court again adhered to the six-hour rule, stating that: ${ }^{16}$

"The applicant had no less than six hours of sleep per night. Moreover, the authorities took steps to ensure that he had enough sleep during at least three nights per week (when he did not take part in court hearings)."

In Strelets v. Russia, the applicant complained of insufficient sleep on days of court hearings. Over several consecutive days, the applicant reported to being woken up at $6 \mathrm{am}$ and being brought back to the cell after $10 \mathrm{pm}$. Notably, the pronouncement of the national court's judgment started at $8.30 \mathrm{pm}$ and finished at $12.30 \mathrm{am}$. Ruling it to be inhuman and degrading treatment, the Court reasoned as follows $(\$ 62)$ :
"the cumulative effect of malnutrition and inadequate sleep on the days of court hearings must have been of an intensity such as to induce in the applicant physical suffering and mental fatigue. This must have been further aggravated by the fact that the above treatment occurred during the applicant's trial, that is, when he most needed his powers of concentration and mental alertness."

Similarly, in Guliyev v. Russia, a prisoner was transported for 65 hours and denied uninterrupted sleep as he was forced to change his position every two hours and subjected to constant light. The Court found the combination of "the duration of the journey, confined space, sleep deprivation, insufficiency of food and possibly inadequate

$\overline{16}$ ECHR. (2016). Sadretdinov v. Russia 17564/06. 
ventilation and lighting" indeed constituted inhuman treatment. ${ }^{17}$

In sum, the cases cited were all considered to amount to inhuman treatment but not torture, possibly due to the intentionality and severity criteria not being met.

There was also insufficient evidence provided to justify the six-hour criterion. We are thus left to speculate when instances of sleep deprivation do and do not constitute torture or other forms of ill-treatment. This is an all too frequent occurrence when applying broad definitions to specific situations.

\section{Intentionality and Purpose}

To locate the distinction between torture and other forms of ill-treatment, we can turn to Manfred Nowak's statement, as the UNSRT, who interpreted the intentionality clause as follows:

" $A$ detainee who is forgotten by the prison officials and suffers from severe pain due to the lack of food is without doubt the victim of a severe human rights violation. However, this treatment does not amount to torture given the lack of intent by the authorities. On the other hand, if the detainee is deprived of food for the purpose of extracting certain information, that ordeal, in accordance with article 1, would qualify as torture. It is also important to underline that the intentional infliction of severe pain or suffering has to be committed for a specific purpose referred to in the Convention, such as the extraction of a confession or information." 18

A similar distinction is therefore found in the literature between intentional and unintentional deprivation of sleep. The former can be described as the deliberate use of sleep deprivation by officials who are aware of its impact, often through stress positions or unrelenting interrogations. The latter usually arises due to the detention environment disrupting sleep such as overcrowding and lack of hygiene or bedding.

In the wake of the widely-reported 1999 Israeli Supreme Court case (HCJ 5100/94-The Public Committee Against Torture in Israel v. The State of Israel et al.), the Israeli State Prosecutor's Office deemed sleep deprivation as a permitted "side effect" of "prolonged interrogation," and not as intentionally used for the purpose of tiring or "breaking" the detainee (Ginbar, 2009, p. 173). Ginbar argues this to be a fig-leaf given what interrogators have, themselves, claimed about their intentional use of sleep deprivation in coercing confessions. In the view of the CAT, this distinction is to be determined objectively, not subjectively. ${ }^{19}$ By extension, recklessness, but not negligence, may also amount to intentionality (Burgers \& Danelius, 1988, p. 118; Mendez \& Nicolescu, 2017, p. 244).

In other words, subjective intentionality on the part of the official should never be required. This is too difficult a determination to make. To do so would allow states to justify that torturing environments arise accidentally.

\section{Preventive Safeguards}

There exists a handful of minimum standards, which primarily relate to interrogation practice and detainee health.

Duration and Method of Interrogation: Principle 21(2) of the UN Body of Principles provides a broad check on harsh, lengthy interrogations and, in turn,

17 ECHR. (2008). Guliyev v. Russia, 24650/02, §64.

18 UNSRT. (2010). Report. A/HRC/13/39/

Add.5, §34.

19 CAT. (2008). General Comment No 2, $\$ 9$. 
acts as a safeguard against the use of sleep deprivation, by proscribing the use of "methods of interrogation which impair... capacity of decision or... judgement."

The Advisory Council of Jurists of the Asia-Pacific Forum of National Human Rights Institutions also put forward its Minimum Interrogation Standards in 2005. ${ }^{20}$ Principle 3 states that: "Individuals should only be interrogated for a reasonable period, taking into account the individual characteristics of the interrogated person and, if extending for a lengthy period, regular breaks should be provided." Again, there is no guidance as to what "reasonable" entails.

Night interrogations are a related area of concern. O'Mara (2015) draws on research on circadian rhythm to find that there is a distinct lack of alertness during night-time hours when compared to the day-time ( $\mathrm{p}$. 152). ${ }^{21} \mathrm{~A}$ recent report on interrogations of Palestinian children in Israel depicts a sleepdeprivation-like use of night interrogations, despite their prohibition:

"Despite these provisions, a quarter of the boys said they were interrogated at night. Moreover, $91 \%$ of boys who provided affidavits for this report and were arrested at home were arrested at night, when most were already in bed, asleep. Even if at least in some of the cases, interrogators waited for 7:00 A.M. (the time stipulated by law) to start the actual interrogation, they were clearly doing no more than following the

20 These standards are not authoritative and are only valuable in terms of expert guidance.

21 Wickens et al. (2015) refer to this as a physiological mechanism 'a cycle of circadian day and circadian night is determined based on when the individual would naturally be awake or asleep. On earth, this is typically coupled to solar night and day.' (p. 934). letter of the law in terms of the prohibition on night-time interrogation (...) The law clearly did not intend that juveniles be taken out of their beds in the middle of the night and then spend the rest of the night at a police station, seated in painful positions without anything to eat or drink, waiting to be interrogated." (B'Tselem and HaMoked, 2017, p. 26)

Principle 6 of the Minimum Interrogation Standards addresses this by stating, "no method of interrogation should be employed that impairs a person's capacity of decisionmaking or judgement. Save in exceptional circumstances, no interrogation should take place at night."

While uses of minimal discomfort arguably remain legitimate (as law enforcement institutions inevitably instill some degree of anxiety), accusatorial, protracted or suggestive interviews overlaid with threats, manipulation and coercion are isolated as being problematic. Indeed, depending on their "degree, severity, chronicity and type, undue psychological pressure and manipulative practices" these behaviors may amount to a form of ill-treatment. ${ }^{22}$ In proposing a protocol for interrogation, the UNSRT recently reported that:

"Torture and ill-treatment harm those areas of the brain associated with memory, mood and general cognitive function. Depending on their severity, chronicity and type, associated stressors typically impair encoding, consolidation and retrieval of memories, especially where practices such as repeated suffocation, extended sleep deprivation and caloric restriction are used in combination. Such practices weaken,

22 UNSRT. (2016). Report. A/71/298, \$44. 
disorient and confuse subjects, distort their sense of time and render them prone to fabricate memories, even if they are otherwise willing to answer questions."23

The broader link between coercive interrogations and sleep deprivation can therefore be made.

Detention Conditions: Rule 13 of the Nelson Mandela Rules also provides that sleeping accommodation should meet all requirements of health and lists a number of key environmental factors required for healthy sleep including "climatic conditions and particularly to cubic content of air, minimum floor space, lighting, heating and ventilation". Principle 4 of the Minimum Interrogation Standards requires similar conditions including: "adequate food, sleep, exercise, changes of clothing, washing facilities and, if needed, medical treatment taking into account any particular characteristics of the individual including age, gender, religion, ethnicity, medical needs, mental illness and any disabilities or other vulnerabilities."

The European Committee for the Prevention of Torture (CPT) has focused on the use of sleep deprivation in interrogation facilities, particularly in its reports on Turkey. In one report, the CPT stated that: "As a rule, a detained person should be allowed within a given period of 24 hours a continuous period of at least eight hours for rest, free from questioning or any activity in connection with the investigation" (CPT, 2009, \$15). In another report, it held that deprivation of sleep for up to several days could be considered as torture (CPT, 2014, \$113). The CPT, it should be acknowledged, does not hold its standards as being absolute and rejects any assessment, given the possibility of alleviating factors, that a "minor deviation from its minimum standards may in itself be considered as amounting to inhuman and degrading treatment of the prisoner(s) concerned" (CPT, 2015, \$21).

UK legislation echoes the CPT in terms of requiring a continuous period of eight hours out of any period of 24 hours "for rest, free from questioning, travel or any interruption in connection with the investigation concerned". Factoring in the circadian rhythm, it is further required that this period "should normally be at night or other appropriate time which takes account of when the detainee last slept or rested". A number of exceptions to this follow. (UK Home Office, 2018, \$12.2)

\section{Documentation}

Given the lack of means to accurately record sleep/rest and interrogation periods, there is also a significant issue with those subjected to sleep deprivation recalling the duration of their suffering. The responsibility to record a detainee's rest, transportation, interrogations and other activities irrefutably falls on the state authorities. Principle 23(1) Minimum Interrogation Standards requires the documentation of the times and intervals between interrogations. In this regard, the European Court of Human Rights has, on a number of occasions, remarked upon the lack of records regarding prisoner rest times and its inability to fully appreciate the factual circumstances. $^{24}$

DIGNITY, in partnership with the Public Committee Against Torture in

$24 \quad$ ECHR, Ireland v. United Kingdom, \19; Separate Opinion of Judge Sir Gerald Fitzmaurice, \$20; ECHR, Strelets v. Russia, \$35.

3 UNSRT. (2016). Report. A/71/298, $₫ 18$. 
Israel (PCATI) and REDRESS, have sought to improve the documentation of sleep deprivation as found in criminal justice settings. A medico-legal protocol, which is currently being validated, developed as part of that project has relied on the research which has informed the article at hand, particularly in terms of informing the questions and the normative background for legal professionals to qualify and argue treatment as torture or ill-treatment (see this issue).

Although there is a level of agreement on the six-hour rule from a legal point of view, as reinforced by medical evidence, more is needed by way of support. Any future pursuit to develop norms vis-à-vis sleep deprivation, to support the emerging standards as advanced by international jurisprudence, must increasingly factor in literature on the health impact.

\section{Conclusions}

Sleep deprivation is a method of torture. It becomes so when prolonged or inflicted in combination with other methods (e.g. threats) and conditions (e.g. disruptive environment or time of day). The dynamics remain ill-defined and somewhat resistant to the development of more nuanced legal principles, as need be informed by available medical and psychological knowledge. Where standards have developed, however, they have been opaque and lacking in strong support, presumably on an everyday understanding on the need for sleep. Although influenced by medical knowledge, the six- or eight-hour rules as expounded by the European bodies have not been based explicitly, nor with sufficient nuance, on known health impacts. Nor have normative declarations by the CAT and UNSRT that link torture and sleep deprivation, whilst necessary, been supported by detailed and clear guidance. For one, the level of impact on capacity and personality, mindful of subjectivities, needs to be better articulated in order to be appreciated as amounting to severe. It may be that more objective and workable rules similar to those developed to define solitary confinement (22/24 hours) and its prolonged use (15 days) under the Nelson Mandela Rules, as universal they may be, are required. As that experience demonstrates, instrumentalizing existing medical knowledge in this vein will only serve to strengthen legal prescriptions against the use of sleep deprivation.

\section{References}

B'Tselem \& HaMoked. (2017). Unprotected; Detention of Palestinian Teenagers in East ferusalem.

Başoğlu, M. (ed). (2017). Torture and Its Definition in International Law: An Interdisciplinary Approach. New York: Oxford University Press. doi. org/10.1093/med/9780199374625.001.0001

Beattie, L., S. D. Kyle, C. A. Espie, \& S. M. Biello. (2015). Social interactions, emotion and sleep: A systematic review and research agenda. Sleep Medicine Reviews, 24, 83-100. doi: 10.1016/j. smrv.2014.12.005

Burgers, J.H, \& Danelius, H. (1988). The United Nations Convention against Torture: A Handbook on the Convention Against Torture and Other Cruel, Inhuman or Degrading Treatment or Punishment. Dordrecht-Boston-London: Martinus Nijhoff.

Cakal, E. (2018). Debility, dependency and dread: On the conceptual and evidentiary dimensions of psychological torture. Torture fournal, 28(2), 1537. doi.org/10.7146/torture.v28i2.106908

CPT. (2011). Turkey: Visit 2009, CPT/Inf (2011) 13.

CPT. (2015). Living space per prisoner in prison establishments: CPT standards, Strasbourg, 15 December 2015, CPT/Inf (2015) 44.

CPT. (2014). Ukraine: Visit 2013, CPT/Inf (2014).

Davis, D., \& Leo, R. (2012). Acute suggestibility in police interrogation: self-regulation failure as a primary mechanism of vulnerability. In A. M. Ridley, F. Gabert, and D. La Rooy (Eds), Suggestibility in legal contexts, 171-95. John Wiley and Sons. doi/ abs/10.1002/9781118432907

Ginbar, Y. (2009) “Celebrating” a Decade of Legalised Torture in Israel.

Griffith, C. D., and S. Mahadevan. (2015). 'Human reliability under sleep deprivation: Derivation 
of performance shaping factor multipliers from empirical data', Reliability Engineering and System Safety, 144, no. Supplement C, 23-34. doi. org/10.1016/j.ress.2015.05.004

Kassin, S. M., Gudjonsson, G. H., \& Kingdom, U. (2004). The psychology of confessions: a review of the literature and issues. Psychological Science in the Public Interest, 5(2), 33-67. doi: 10.1111/j.1529-1006.2004.00016.x

Leach, J. (2016). Psychological factors in exceptional, extreme and torturous environments. Extreme Physiology E Medicine 5:7. doi:10.1186/s13728016-0048-y

Lowe, C.J., Safati, A., \& Hall, P. A.. (2017). The neurocognitive consequences of sleep restriction: A meta-analytic review. Neuroscience E Biobehavioral Reviews, 80, 586-604. doi: 10.1016/j.neubiorev.2017.07.010

Mendez, J., \& Nicolescu, A., (2017). Evolving Standards for Torture in International Law. In Basoglu, M. Torture and Its Definition in International Law: An Interdisciplinary Approach (pp. 215-245). New York: Oxford University Press. doi:10.1093/ med/9780199374625.001.0001

O'Mara, S. (2015). Why Torture Doesn't Work: The Neuroscience of Interrogation. Cambridge, MA: Harvard University Press. doi: 10.13140/ RG.2.1.2038.2246

Pérez-Sales, P. (2017). Psychological Torture: Definition, Evaluation and Measurement. London: Routledge. doi: $10.4324 / 9781315616940$

Physicians for Human Rights \& Human Rights First. (2007). Leave No Marks: "Enhanced" interrogation techniques and the risk of criminality.

Pilcher, J.J., \& Huffcutt, A. I.. (1996). Effects of sleep deprivation on performance: a meta-analysis. Sleep, 19(4), 318-326.

Pires, G. N., A. G. Bezerra, S. Tufik, and M. L. Andersen. (2016). Effects of acute sleep deprivation on state anxiety levels: a systematic review and meta-analysis. Sleep Medicine, 24, 109-118. doi: 10.1016/j.sleep.2016.07.019

Rejali, D. (2007). Torture and Democracy. Princeton, NJ: Princeton University Press.

UN Body of Principles for the Protection of All Persons under Any Form of Detention or Imprisonment, GA Res 43/173 of 9 December 1988.

United Kingdom Home Office (2018). Police and Criminal Evidence Act 1984, CODE C: Revised Code of Practice for the detention, treatment and questioning of persons by Police Officers.

United States Army. (2006). Appendix M of the Army Field Manual Human Intelligence Collector
Operations, FM 2-22.3 of September 2006. Wickens, C. D., S. D. Hutchins, L. Laux, and A. Sebok. (2015). The Impact of Sleep Disruption on Complex Cognitive Tasks: A MetaAnalysis. Human Factors, 57(6), 930-946. doi: 10.1177/0018720815571935 